\title{
Analysis and mapping of mining subsidence and underground voids collapse risk using GIS and the weights-of-evidence model for the abandoned Ichmoul mine, Algeria
}

\author{
Nassim Larachi, Abderrahim Bali, Abderrezak Ait Yahiatene and Malek Ould Hamou
}

\begin{abstract}
The present study concerns the assessment of mining subsidence and old underground works collapse hazard of the abandoned Ichmoul mine (Batna, Algeria) using the geographic information system (GIS) and the weight of evidence method (WofE). After the identification of collapse cases on the site and developing a spatial database for old underground works, topography and geology, the weight of evidence model was applied to calculate the weight of each relevant factor. Five main factors controlling or related to subsidence and underground voids collapse were determined from the probability analysis of existing cases; the underground voids depth, the distance between the underground voids, the landforms slope, the lithology and the distance between the fractures. Conditional independence tests were performed for the choice of factors. For the analysis of the subsidence and underground void collapse spatial hazard mapping, the contrast values, $\mathrm{W}^{+}$and $\mathrm{W}^{-}$of the each factor evaluation were analyzed. The analysis results were validated using the curve ROC (AUC) with a past collapse case. For all the factors used, the area under the (ROC) curve showed $92 \%$ accuracy. The results obtained can be used for the prevention of mining subsidence and underground voids collapse risks and the mine site rehabilitation.
\end{abstract}

Keywords-Abandoned mine, Algeria, geographic information system, hazard prediction map, subsidence and collapse hazard, weight of evidence.

\section{INTRODUCTION}

Abandoned mines are threatened by the ground subsidence and voids collapse risk around old mining works (galleries, pipes, declines, shafts, etc.). This risk with negative environmental impact [1-7] is only a spatio-temporal evolution of the voids physical instability that was once created by the underground exploitation of deposits. Therefore, managing the mining subsidence and voids collapse risk of abandoned mine is urgent and imminent, in order to reduce the impact and so that governments can prevent this risk. So, a systematic prediction of subsidence and voids collapse can be used for sustainable development and future management of the post-mine environment. Although the GIS (geographic information system) has been widely used for geo-risks such as landslides [8-11], floods [12, 13], land subsidence by overexploitation groundwater [14], groundwater vulnerability to pollution [1518], soil erosion [19-21], soil pollution [22]... etc. and even in the mineral resources potential assessment [23-26], few studies have been carried out for the assessment of GIS-based methods and applications relating to the environmental management of

\footnotetext{
Manuscript received May 16 , 2021; revised September 15, 202.

N. Larachi is with Faculty of Nature and Life Sciences, University of Bejaia, Bejaia, ALGERIA and with Mining Engineering Department, Ecole Nationale Polytechnique Algiers, ALGERIA.

(e-mail:nassimlarachi@yahoo.fr).

A. Bali is with Materials of Civil-Engineering and Environment laboratory, Ecole Nationale polytechnique Algiers, ALGERIA (e-mail:abderrahim.bali@g.enp.edu.dz).

A. Ait Yahiatene and M. Ould Hamou are with Mining Engineering Department, Ecole Nationale Polytechnique Algiers, ALGERIA. (e-mail: abderrezak.aityahiatene@g.enp.edu.dz, malek.ouldhamou@g.enp.edu.dz).
}

Digital Object Identifier (DOI): 10.53907/enpesj.v1i2.46 former mining sites [27]. In recent years, there have been probability, statistical, fuzzy logic and artificial neural network methods combined with GIS (Geographic Information System) software that helps predict the subsidence and collapse risk in the mining environment. Indeed, Kim et al., 2006; Blachwski, 2016; Oh et al., 2011 and Lee et al., 2012 predicted the ground subsidence risk using GIS with models based on frequency ratio, logistic regression and an artificial neural network [2831], Choi et al., 2010 and Park et al., 2012 predicted this risk for an abandoned underground coal mine out of fuzzy logic [32,33]. Oh and Lee, 2011; 2010 also applied the weights of evidence (WofE) method to predict subsidence in an abandoned coal mine [34, 35]. Algeria has old mines, dispersed throughout the country. The various geological risks of old mines, including mine drainage, ground subsidence and voids collapse, contamination, etc. are important in these mines [36]. Very little attention has been paid to the subsidence and collapse risk at these mine sites. Therefore, the Algerian government must initiate research programs on former mining sites in order to carry out data mining for post-mine management. During the sampling campaigns of the mine wastes and geo-mining study on the abandoned Ichmoul mine allowed to identify and observe subsidence and collapse cases around the old galleries (Fig.1). So, a prediction method combined with MapInf software to assess and predict mine subsidence and collapse is applicable. The objective of this study is to analyze and map the land subsidence and underground collapse risk of around the old galleries of the abandoned Ichmoul mine using the weights-of-evidence method and GIS.

\section{Methodology}

The analysis of the mining subsidence and voids collapse risk of mine sites with underground exploitation requires several steps $[30,32,33,35]$. The first step involves the collection of mining (mining plans), geological (lithology, faults), 


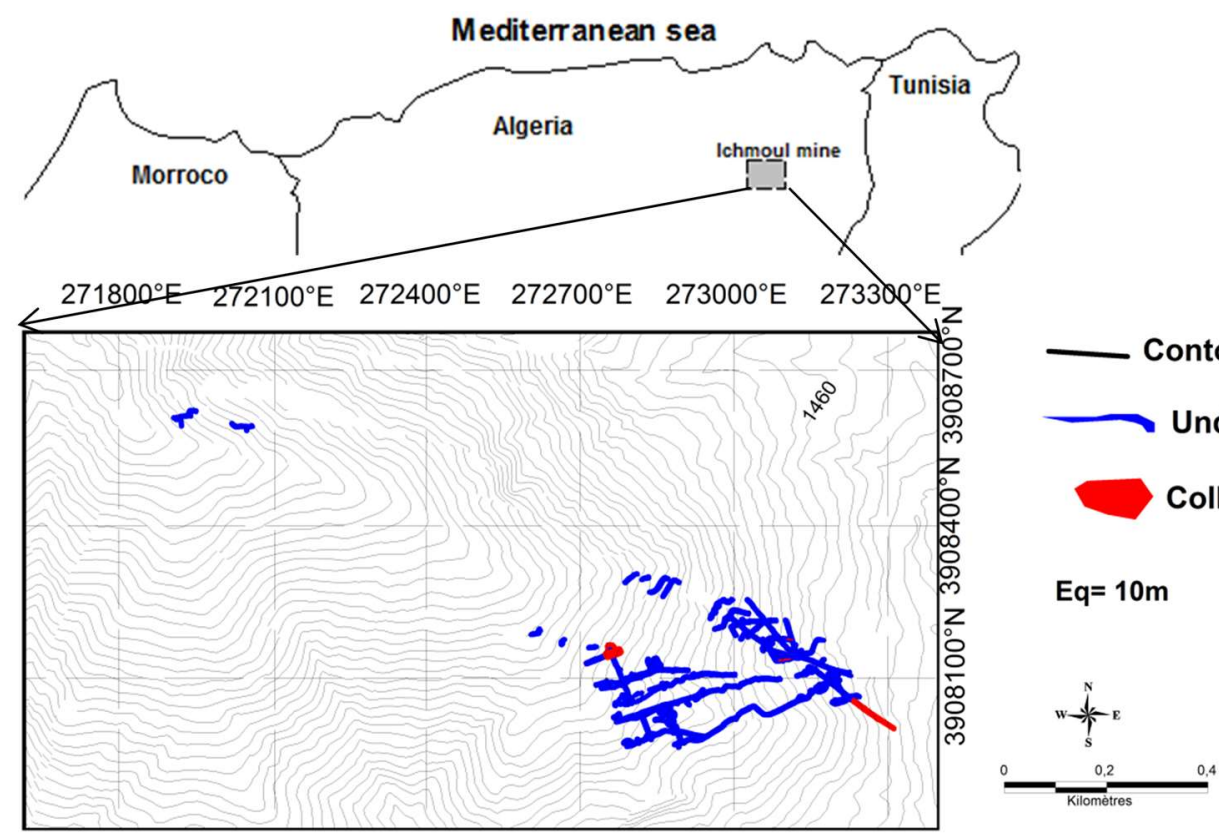

Fig. 1: Old mining galleries and underground collapse location of the abandoned Ichmoul mine site.

hydrogeological, topographic (landform slopes) data as well as an inventory of subsidence and collapse cases on the site. These data will allow selection of the relevant factors. The second step is to assess the spatial hazard using the relationship between this risk and factors related. The third step is to make a risk map of subsidence and underground voids collapses from the factor maps. Finally, the results validation step. Ground subsidence and voids collapse in mine sites are processes of rock mass movement under the influence of various factors. Therefore, it is essential to analyze the conditions of the selected factors to assess this risk. In the literature, the main influencing factors responsible for mining subsidence and voids collapse are the depth and height of underground voids, mining method, degree of voids inclination, mining extent, structural geology, lithology, landforms slope and groundwater [33, 35].In addition, two campaigns carried out on the mine site detected mining subsidence and voids collapse cases (Fig.2), some were used for modeling and others for validation.
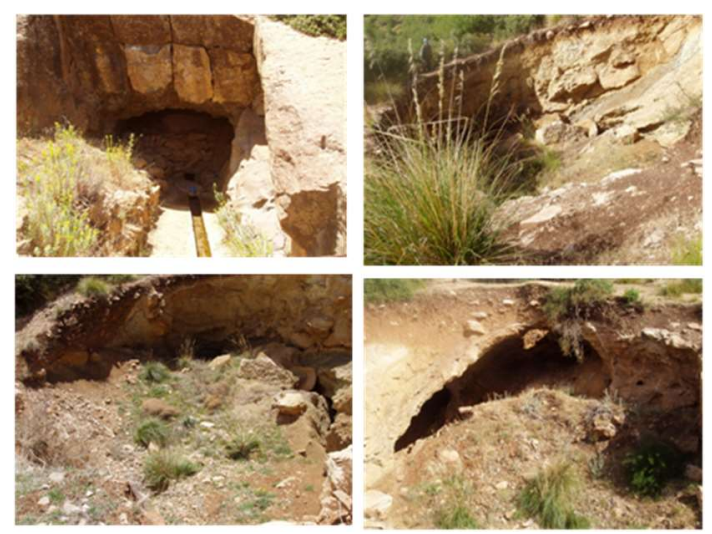

Fig. 2: Collapse cases of galleries in the Ichmoul mine site.

A total of 5 cases mapped through field observations. Of the total, a case was mapped to ore masse 3 that caused a land subsidence. A large number of ground breaking phenomena have been observed at high altitudes. It was found that these collapses mainly occurred on the access galleries openings. The escalating feature of collapses has proven to be a major risk for artisanal miners. The study area belongs to the terrain comprising a variety of different dimensions faults. The main one is the tectonic fault located in the ore masse 2 and 4.
The approach to predicting mining subsidence and collapses around voids generated by old mining is based on the spatial correlation of factors and risk. To generate the risk prediction maps for each of the five study factors using WofE, the spatial database was classified into a map by calculating $\mathrm{W}+$ and $\mathrm{W}-$ from "(1)" and "(2)" [10, 35], which show favorable and unfavorable areas.

$$
\begin{aligned}
& W^{+}=\log \frac{P\{B / D\}}{P\{B / \bar{D}\}} \\
& W^{-}=\log \frac{P\{\bar{B} / D\}}{P\{\bar{B} / \bar{D}\}}
\end{aligned}
$$

where $\mathrm{P}$ is the probability, $\mathrm{B}$ is the presence of a dichotomous pattern,

$\bar{B}$ is the absence of a dichotomous pattern, $\mathrm{D}$ is the presence of an event occurrence, and $\bar{D}$ is the absence of an event occurrence. $\mathrm{W}^{+}$and $\mathrm{W}^{-}$are the weights of proof when a factor is present (relevant) and absent (irrelevant), respectively.

A pair of weights, $\mathrm{W}^{+}$and $\mathrm{W}^{-}$, is determined by the degree of overlap between known mining subsidence and collapses and the various classes of factors [11, 34]. If no particular association exists between the collapse occurrences and the factor, then $\mathrm{W}^{+}=\mathrm{W}^{-}=0$. A positive value of $\mathrm{W}^{+}$indicates a positive association between known cases and the obvious map. The contrast value $\mathrm{C}$ (where $\mathrm{C}=\left[\mathrm{W}^{+}\right]-\left[\mathrm{W}^{-}\right]$) represents the degree spatial association between the obvious map and known occurrences [11]. The weights significance $(\mathrm{S})$ can be estimated by " $(3,4)$ " below $[10,11]$ :

$$
\begin{aligned}
& \mathrm{s}^{2}\left(W^{+}\right)=[1 / M\{B \cap D\}]+[1 / M\{B \cap \bar{D}\}] \\
& \mathrm{s}^{2}\left(W^{-}\right)=[1 / M\{\bar{B} \cap D\}]+[1 / M\{\bar{B} \cap \bar{D}\}]
\end{aligned}
$$

Finally, to calculate the standard deviation and the studentized (c/s) of the contrast, "(5)" and "(6)" were used $[35,11,14]$.

$$
\mathrm{S}(\mathrm{C})=\sqrt{\mathrm{s}^{2}\left(\mathrm{~W}^{+}\right)+\mathrm{s}^{2}\left(\mathrm{~W}^{-}\right)}
$$




$$
\mathrm{c} / \mathrm{s}=(\mathrm{C} / \mathrm{S}(\mathrm{C}))
$$

\section{RESULTS AND DISCUSSION}

These past cases of subsidence and voids collapse will help select the relevant factors related to risk. They ensure also that the predicted subsidence and voids collapse will occur under conditions identical to those of the past cases [32].

On the other hand, a laborious work made it possible to develop geographic information system (GIS) using professional
The slope was classified into 10 categories after eliminating certain elevations. Since the distance between fractures factor is relevant, then fractures were included.

The lithology factor has been classified into 6 categories.

Then, using the weight-of-evidence method, the spatial relationships between the location of the detected underground voids collapse and each of the underground voids collapse related factors, such as slope, faults, depth of voids, distance between voids, the depth of voids were analyzed (Table II). Spatial relationships were used as a rating for each factor in the overlay analysis. Subsequently, conditional independence tests were carried out for the selection of factors to be used in the

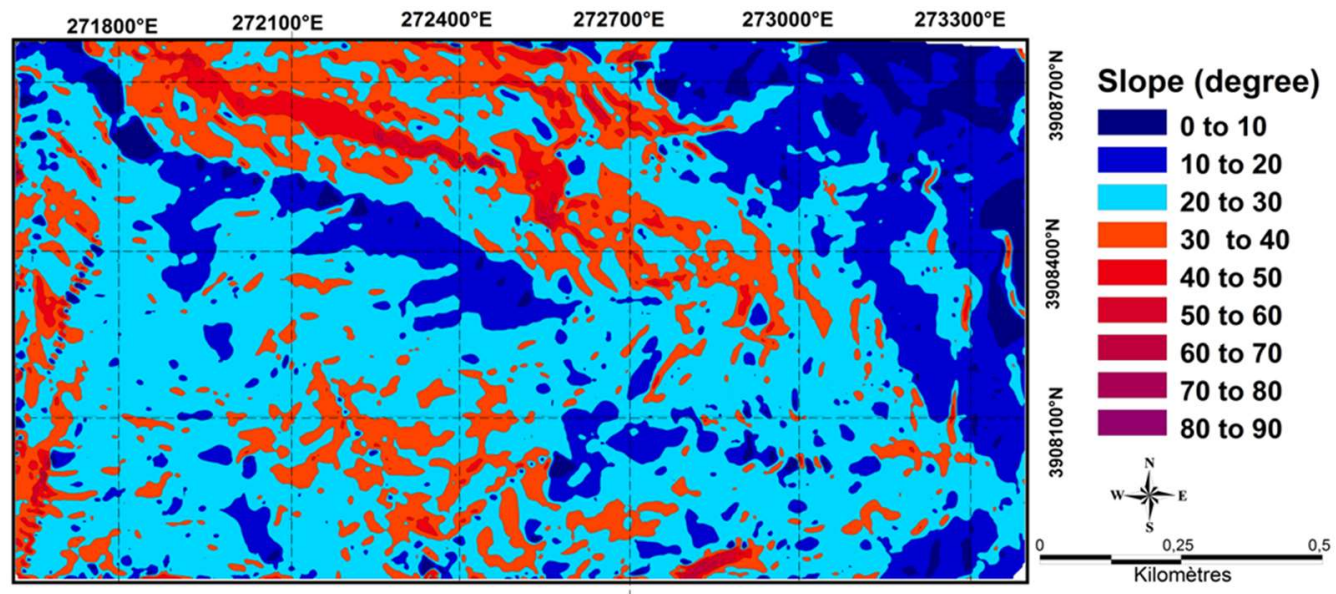

Fig. 3: Class map of the landform slope factor of the Ichmoul mine site.

MapInfo software while digitizing and calibrating the various mapping of spatial subsidence and collapse hazard [35]. maps (paper format) recovered from the National Mining Company of Products Non Ferrous and useful substances (ENOF). This GIS database is made up of the contour lines altitudes generated from a topographic map, lithological

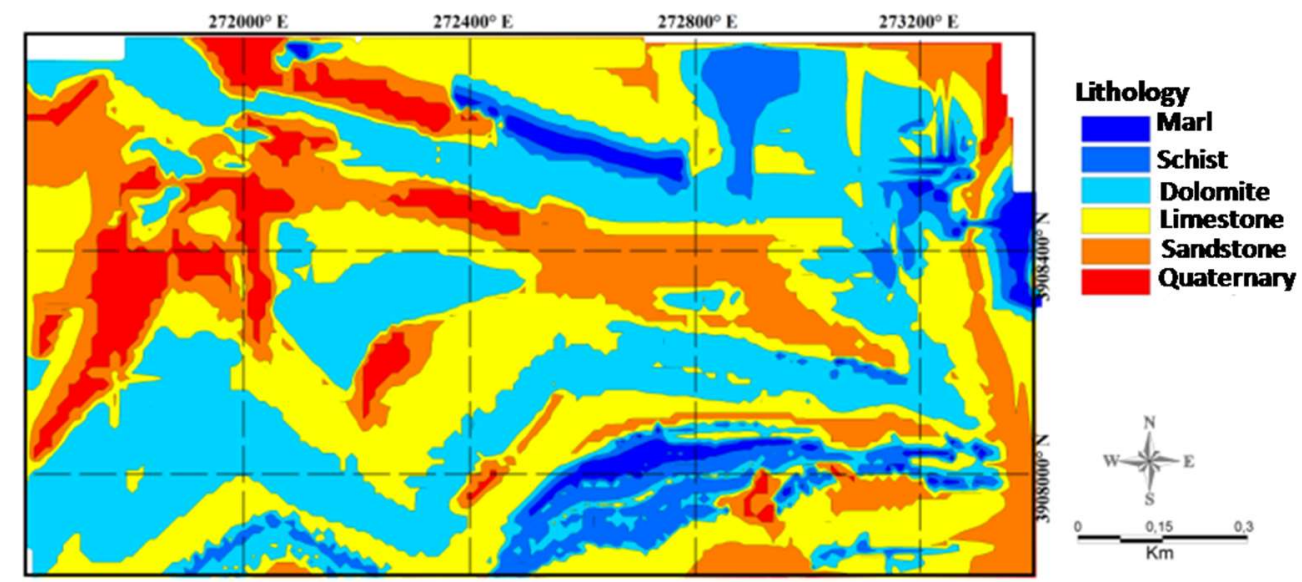

Fig. 4: Class map of the lithology factor of the Ichmoul mine site.

information and the faults from the geological map, distances between the old underground voids from the old galleries maps and the old voids depths from geological sections. The thematic data layers are shown in Table I and Figs. 3-7.

Previous studies of ground subsidence in old mine sites have mentioned that void depth factors and the distances between them are important $[28,30,33]$, therefore very tight classes were chosen. However, the hydrogeology factor has been eliminated because the Ichmoul mine is above groundwater [37]. The section factors of underground voids and mining method were also eliminated because during the study campaigns on the site, it was observed that the underground voids have small cross-section and the mining is not well developed.
Table. I

CONSTRUCTION OF A GIS DATABASE INCLUDING FACTORS RELATED TO THE MINING SUBSIDENCE AND UNDERGROUND VOIDS COLLAPSE OF THE ABANDONED ICHMOUL MINE.

\begin{tabular}{lll}
\multicolumn{3}{c}{ ABANDONED ICHMOUL MINE. } \\
\hline \hline Category & Factors & Scale \\
& & \\
\hline Geology map & Distance between fractures & \\
& Lithology & $1 / 2000$ \\
Topographic map & Slope & $1 / 2000$ \\
Galleries maps & Distance between underground voids & $1 / 2000$ \\
& & and $1 / 500$ \\
\hline \hline
\end{tabular}




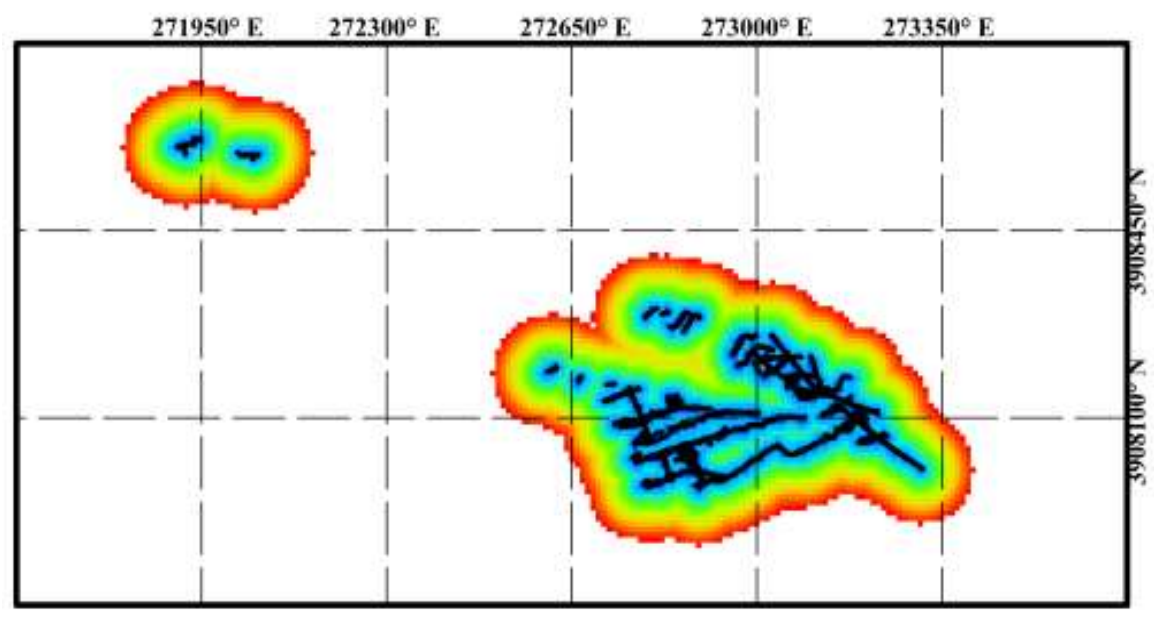

Distance from underground void (meter)

Fig. 5: Class map of distance between underground voids factor of the Ichmoul mine site.

The factors were added to calculate a spatial risk index of etc., in one step. The 5 factor maps were submitted to the large subsidence and underground voids collapse hazard was mapped WofE tool of the MI-SDM, which resulted in a large table for 5 factors combinations such as a combination using all (Table II) containing $\mathrm{W}^{+}, \mathrm{W}^{-}, \mathrm{C}, \mathrm{S}^{2}\left(\mathrm{~W}^{+}\right), \mathrm{S}^{2}\left(\mathrm{~W}^{-}\right), \mathrm{S}^{2}(\mathrm{C})$ and

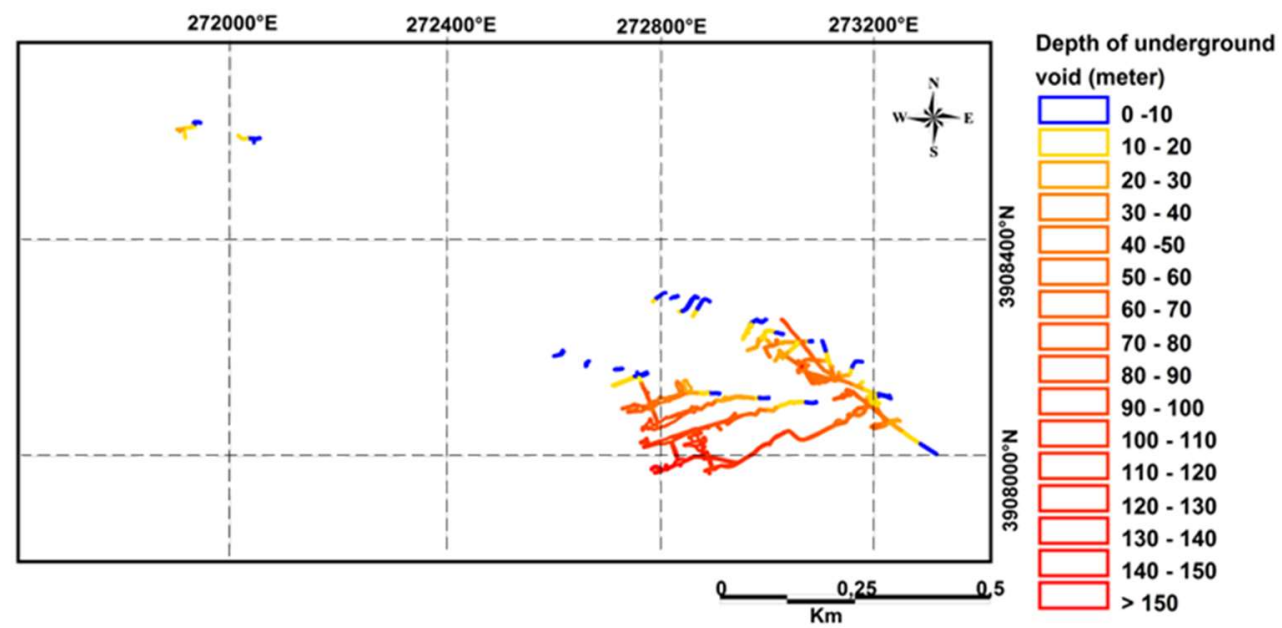

Fig.6: Class map of the underground voids depth factor of the Ichmoul mine site.

variables and 4 others different combinations (without depth of C/S (C) information of each the factor classes using "(1-6)".It voids, without distance between fracture, without slope, also resulted in a posterior probability map containing the without distance of underground voids). Then, 5 posterior probability information (in a range of 0 to 1 ) of the void probability maps were generated (Figs. 8 and 9). Finally, the collapse occurrence, cell by cell. Positive C values are observed results of combining all the factors were validated using the in the five selected factors, steep slope category (30 -50), receiver operating characteristic curve (ROC) with previous lithology (limestone, dolomite and shale), shallow depth (0-20 underground voids collapse cases $[30,35]$. $\mathrm{m})$, distance between fractures $(0-20,80-90 \mathrm{~m})$ and short

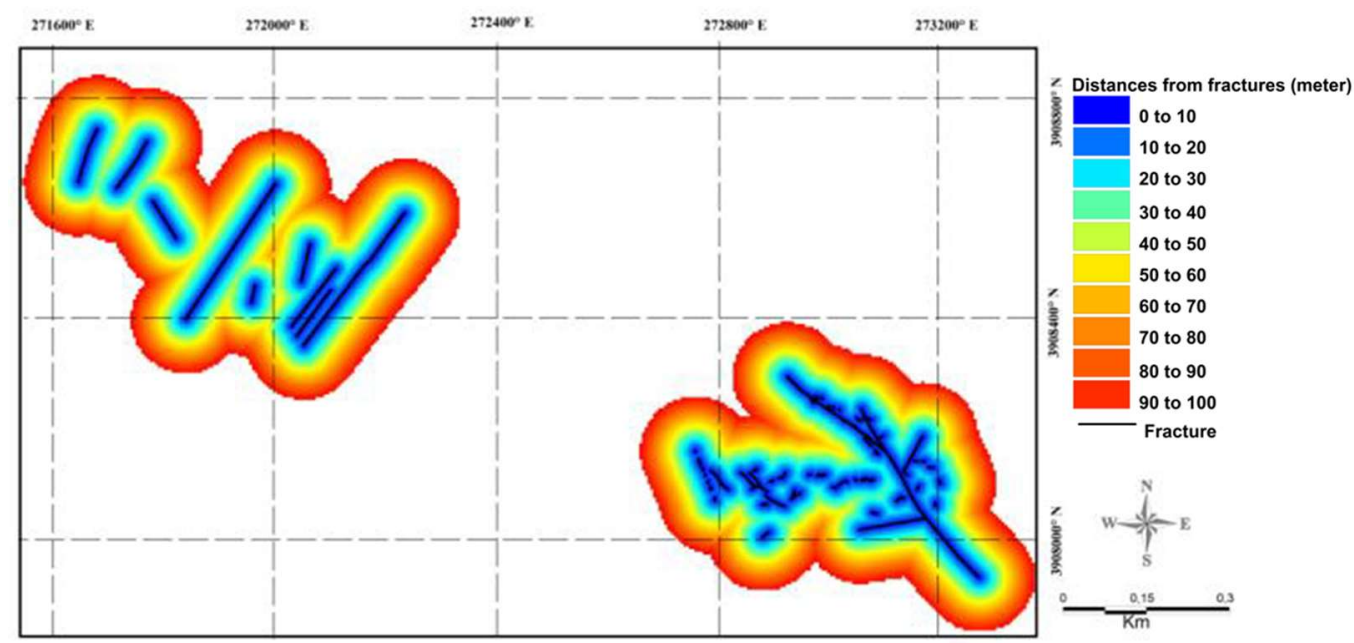

Fig. 7: Class map of the distance between fractures factor of the Ichmoul mine site.

distance between voids (0-20m).This indicates that these The WofE application in this study, the MI-SDM extension of categories of factors influence the subsidence and underground MapInfo 8 professional software was used. The plugin has voids collapse prediction at the former Ichmoul mine. several tools to calculate the posterior probability map with a tool that calculates $\mathrm{W}^{+}, \mathrm{W}^{-}$and the posterior probability map, 
Table. II

ANALYSIS OF WEIGHTS OF EVIDENCE BETWEEN MINING SUBSIDENCE AND UNDERGROUND VOIDS COLLAPSE AND RELATED FACTORS

\begin{tabular}{|c|c|c|c|c|c|c|c|c|c|c|}
\hline Factor & Class & $\begin{array}{l}\text { Area } \\
\left(\mathrm{km}^{2}\right)\end{array}$ & point & $\mathrm{W}^{+}$ & $\mathrm{S}\left(\mathrm{W}^{+}\right)$ & $\mathrm{W}^{-}$ & $\mathrm{S}\left(\mathrm{W}^{-}\right)$ & Contrast & $\mathrm{S}(\mathrm{C})$ & Stud (C) \\
\hline andform & $0-10$ & 35 & 0 & - & - & - & - & - & - & - \\
\hline \multirow{13}{*}{ lope (\%) } & $10-20$ & 177 & 10 & -1.930 & 0.3256 & 0.2816 & 0.0803 & -2.2115 & 0.3553 & -6.5955 \\
\hline & $20-30$ & 452 & 132 & -0.0001 & 0.1034 & 0.0001 & 0.1094 & -0.0002 & 0.1506 & -0.0014 \\
\hline & $30-40$ & 158 & 98 & 1.3760 & 0.1639 & -0.3933 & 0.0917 & 1.7694 & 0.1878 & 9.4199 \\
\hline & $40-50$ & 27 & 10 & 0.3548 & 0.3985 & -0.0124 & 0.0766 & 0.3672 & 0.4058 & 0.9047 \\
\hline & $50-60$ & 0 & 0 & - & - & - & - & - & - & - \\
\hline & $60-70$ & 0 & 0 & - & - & - & - & - & - & - \\
\hline & $70-80$ & 0 & 0 & - & - & - & - & - & - & - \\
\hline & $80-90$ & 0 & 0 & - & - & - & - & - & - & - \\
\hline & missing & 144 & -75 & - & - & - & - & - & - & - \\
\hline & Marl & 17 & 0 & - & - & - & - & - & - & - \\
\hline & Schist & 58 & 21 & 0.6887 & 0.27332 & -0.0611 & 0.0874 & 0.7497 & 0.2869 & 2.6126 \\
\hline & Limestone & 283 & 138 & 1.2056 & 0.1189 & -1.0895 & 0.1495 & 2.2951 & 0.1911 & 12.0116 \\
\hline & Dolomite & 279 & 28 & -0.9382 & 0.1992 & 0.3201 & 0.0936 & -1.2583 & 0.2201 & -5.7160 \\
\hline \multirow[t]{4}{*}{ lithology } & Sandstone & 155 & 0 & - & - & - & - & - & - & - \\
\hline & Quaternary & 48 & 0 & - & - & - & - & - & - & - \\
\hline & Missing & 157 & 0 & - & - & - & - & - & - & - \\
\hline & $0-10$ & 11 & 6 & 23224 & 0.6055 & -0.6429 & 0.4207 & 2.9653 & 0.7373 & 4.0217 \\
\hline \multirow{18}{*}{$\begin{array}{l}\text { Jnderground } \\
\text { oids depth } \\
\text { m) }\end{array}$} & $10-20$ & 13 & 4 & 13291 & 0.6009 & -0.3131 & 0.3684 & 1.6422 & 0.7049 & 2.3298 \\
\hline & $20-30$ & 12 & 1 & -0.2578 & 1.0445 & 0.0271 & 0.3192 & -0.2849 & 1.0922 & -0.2609 \\
\hline & $30-40$ & 12 & 0 & - & - & - & - & - & - & - \\
\hline & $40-50$ & 12 & 1 & -0.2578 & 1.0445 & 0.0271 & 0.3192 & -0.2849 & 1.0922 & -0.2609 \\
\hline & $50-60$ & 8 & 0 & - & - & - & - & - & - & - \\
\hline & $60-70$ & 6 & 0 & - & - & - & - & - & - & - \\
\hline & $70-80$ & 8 & 0 & - & - & - & - & - & - & - \\
\hline & $80-90$ & 6 & 0 & - & - & - & - & - & - & - \\
\hline & $90-100$ & 5 & 0 & - & - & - & - & - & - & - \\
\hline & $100-110$ & 7 & 0 & - & - & - & - & - & - & - \\
\hline & $110-120$ & 2 & 0 & - & - & - & - & - & - & - \\
\hline & $120-130$ & 3 & 0 & - & - & - & - & - & - & - \\
\hline & $140-150$ & 1 & 0 & - & - & - & - & - & - & - \\
\hline & $150-160$ & 1 & 0 & - & - & - & - & - & - & - \\
\hline & $0-10$ & 75 & 12 & 1.6081 & 0.3150 & -1.7576 & 0.7094 & 3.3657 & 0.7762 & 4.3360 \\
\hline & $10-20$ & 44 & 2 & 0.2218 & 0.7237 & -0.0326 & 0.2940 & 0.2544 & 0.7812 & 0.3257 \\
\hline & $20-30$ & 38 & 0 & - & - & - & - & - & - & - \\
\hline & $30-40$ & 34 & 0 & - & - & - & - & - & - & - \\
\hline \multirow{9}{*}{$\begin{array}{l}\text { Distances } \\
\text { between } \\
\text { nderground } \\
\text { voids }(\mathrm{m})\end{array}$} & $40-50$ & 33 & 0 & - & - & - & - & - & - & - \\
\hline & $50-60$ & 33 & 0 & - & - & - & - & - & - & - \\
\hline & $60-70$ & 31 & 0 & - & - & - & - & - & - & - \\
\hline & $70-80$ & 31 & 0 & - & - & - & - & - & - & - \\
\hline & $80-90$ & 34 & 0 & - & - & - & - & - & - & - \\
\hline & $90-100$ & 25 & 0 & - & - & - & - & - & - & - \\
\hline & missing & 1619 & -1 & - & - & - & - & - & - & - \\
\hline & $0-10$ & 60 & 5 & 1.0521 & 0.4671 & -0.2591 & 0.3052 & 1.3112 & 0.5580 & 0.3501 \\
\hline & $10-20$ & 60 & 3 & 0.5055 & 0.5923 & -0.0876 & 0.2814 & 0.5932 & 0.6558 & 0.9045 \\
\hline \multirow{9}{*}{$\begin{array}{l}\text { )istances } \\
\text { 3etween } \\
\text { ractures (m) }\end{array}$} & $20-30$ & 56 & 0 & - & - & - & - & - & - & - \\
\hline & $30-40$ & 56 & 0 & - & - & - & - & - & - & - \\
\hline & $40-50$ & 53 & 2 & 0.2113 & 0.7208 & -0.0268 & 0.2714 & 0.2382 & 0.7702 & 0.3092 \\
\hline & $50-60$ & 49 & 1 & -0.4212 & 1.0104 & 0.0355 & 0.2624 & -0.4568 & 1.0439 & -0.4376 \\
\hline & $60-70$ & 47 & 1 & -0.3787 & 1.0108 & 0.0312 & 0.2624 & -0.4098 & 1.0443 & -0.3924 \\
\hline & $70-80$ & 47 & 1 & -0.3787 & 1.0108 & 0.0312 & 0.2624 & -0.4098 & 1.0443 & -0.3924 \\
\hline & $80-90$ & 47 & 3 & 0.7644 & 0.5967 & -0.1163 & 0.2812 & 0.8807 & 0.6597 & 1.3351 \\
\hline & $90-100$ & 41 & 0 & & & & & & & \\
\hline & missing & 1480 & -3 & & & & & & & \\
\hline
\end{tabular}

\section{A. Mapping of the subsidence and underground voids} collapse risk of Ichmoul mine

As mentioned in the previous section, the posterior probabilities should not be considered in absolute terms, but as a relative term of subsidence and underground voids collapse favorability, which can be represented by the relative map of this instead of using the true posterior probability values. MISDM's WofE generates a continuous raster, which represents the void collapse probability on a continuous scale from 0 (minimum) to 1 (maximum). In the present study, a minimum probability value of 0.0001 and a maximum of 0.4660 were observed (Fig. 8).

In addition, 4 other combinations of factors were studied and the posterior probability maps were generated (Fig.9).Each map shows different probability values, indicating the effect of each factor on the prediction of the subsidence and underground voids collapse risk in the mine site. Indeed, combination 1 (without depth of voids) and combination 2 (without distance between fractures), show low posterior probability values compared to the other combinations, which suggests that they are the main risk factors for subsidence and underground voids collapse in the Ichmoul mining site.

\section{B. Conditional independence test (CI)}

Conditional independence was tested before integrating predictor maps to map the spatial hazard of subsidence and underground voids collapse. All pairs of factors selected for prediction were tested, and a chi-square table $\mathrm{X}^{2}$ to test conditional independence is shown in Table III. 


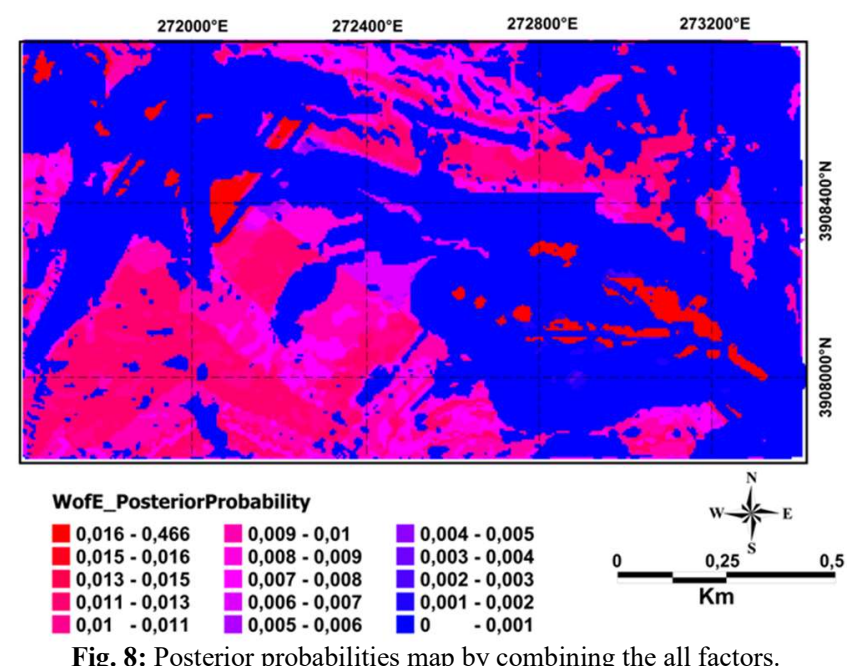

The theoretical $\mathrm{X}^{2}$ value of 6.63 to test conditional and the lithology factor is presented in Table III. It can be seen independence between all pairs of models for each factor was that these two factors show conditional independence, because calculated to the significance of $95 \%$ and 1 degree of freedom. the calculated $X^{2}$ is 0.44 and which is less than theoretical $X^{2}$. If the calculated $\mathrm{X}^{2}$ value is less than 4.84 , the pair of prediction This implies that these predictors could be used together to map factors is independent. For example, using the possibility table the spatial hazard of subsurface void collapse at the Ichmoul to test the conditional independence between the slope factor mine site.
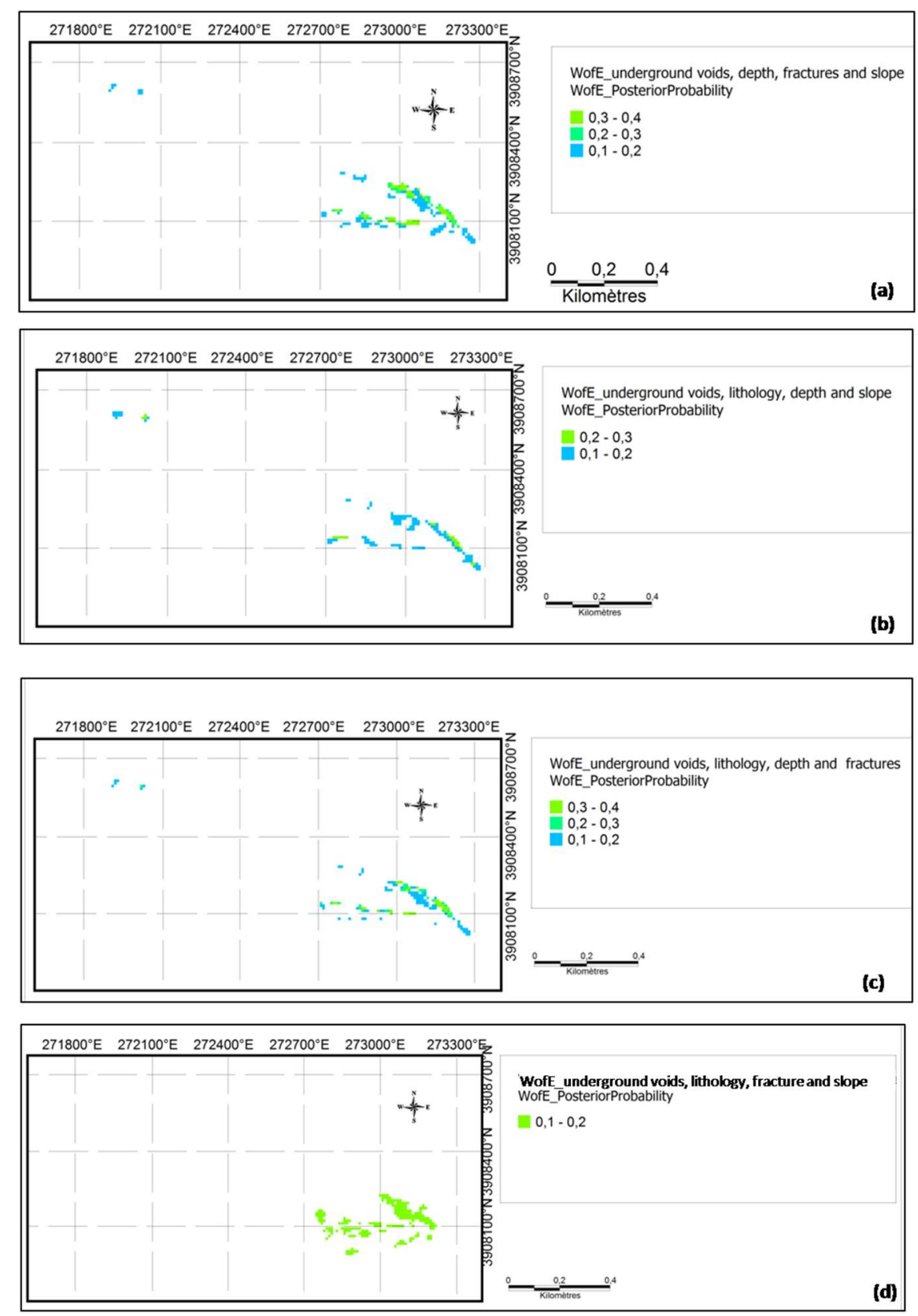

Fig. 9: Class Posterior probability maps for factors combinations (a) without lithology (b) without distance between fractures(c) without landforms slope (d) without underground voids depth 
Table. III

CHI-SQUARE VALUES CALCULATED TO TEST THE CONDITIONAL INDEPENDENCE BETWEEN THE FACTORS SELECTED FOR THE ICHMOUL MINE SITE (PROBABILITY OF TEST RELIABILITY OF $5 \%$ )

\begin{tabular}{|c|c|c|c|c|c|}
\hline & $\begin{array}{l}\text { Underground } \\
\text { voids depth }\end{array}$ & $\begin{array}{l}\text { Distances } \\
\text { between } \\
\text { fractures }\end{array}$ & $\begin{array}{l}\text { Distances } \\
\text { between } \\
\text { underground } \\
\text { voids }\end{array}$ & lithology & Slope \\
\hline $\begin{array}{l}\text { Underground } \\
\text { voids depth }\end{array}$ & - & 3.329 & $\mathbf{0}$ & 1.876 & 1.202 \\
\hline $\begin{array}{l}\text { Distances } \\
\text { between fractures }\end{array}$ & & - & 0 & 4.179 & 1.977 \\
\hline $\begin{array}{l}\text { Distances } \\
\text { between } \\
\text { underground } \\
\text { voids }\end{array}$ & & & - & 0 & 0 \\
\hline lithology & & & & - & 0.446 \\
\hline Slope & & & & & - \\
\hline
\end{tabular}

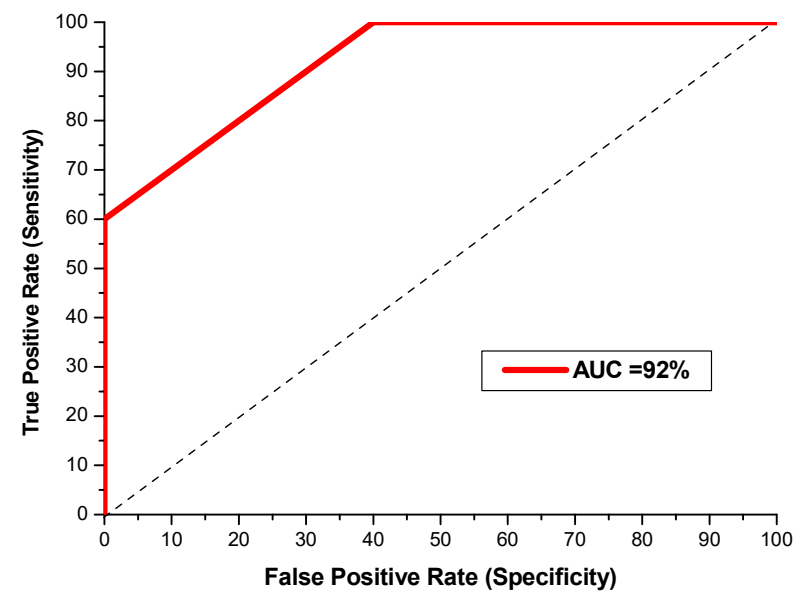

Fig. 11: The ROC (AUC) curve for validation of a prediction map of the underground voids collapse risk in the abandoned Ichmoul mine.

\section{CONCLUSION}

Mapping the risk of subsidence and voids collapse generated by mining is a fundamental tool for the environmental management of former mining sites. This study demonstrates the influence of landforms slope, underground voids depth and
The risk map of mining subsidence and underground voids collapse in the Ichmoul mine site was then produced, using all the factors, and the risk index is shown in Fig.10.

The index was classified into 4 classes depending on the area for visual and easy interpretation: high, medium, low and very low.

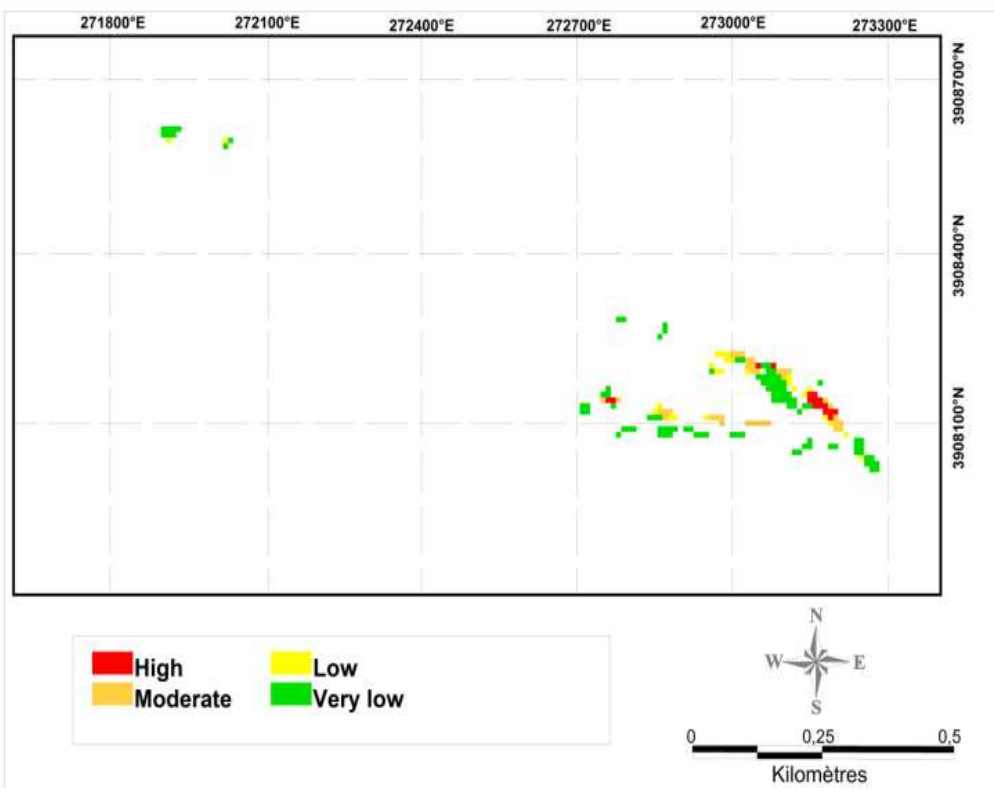

Fig. 10: The risk prediction map of underground voids collapse in the Ichmoul mine site.

\section{Validation}

The purpose of the validation is to verify the quality and accuracy of the approach applied for the prediction of subsidence and collapse around the old underground voids of the abandoned Ichmoul mine. For this purpose, the generated risk map was validated using the ROC AUC (Area Under the Curve) result. This curve was obtained by comparing the rate of false positives (1-specificity) and the rate of true positives (sensitivity) of the posterior probability map [26]. This curve (Fig.11) was also formed using the underground voids collapse case risk not used for the prediction. The area of this spared case was divided into 30 zones, each of which is approximately $20 \mathrm{~m}^{2}$ and the posterior probability value of each was taken.

The value of the area under the curve is $92 \%$, which shows the precision and perfection of the approach applied for the prediction of mining subsidence and underground voids collapse risk of the Ichmoul mine site. their distances, distance between fractures, and lithology factors on mining subsidence and underground voids collapse and their potential distribution in the abandoned Ichmoul mining site. The Subsidence and underground voids collapse risk map produced by the WofE method has been classified into four classes: very low, low, medium and high. The map obtained was validated according to the ROC (AUC) test, the precision was $92 \%$. The results of this study can be used to map the subsidence and underground voids collapse risk at other mine sites. In addition, the risk map of subsidence and underground voids collapse can be used as basic data for the establishment of a risk prevention plan in old mining sites. However, to generalize mine subsidence and underground voids collapse factors, more studies and prediction methods should be performed.

\section{ACKNOWLEDGMENT}

The authors are grateful to the management staff of Ain Mimoun mine (Khenchela, Algeria) for their collaboration during outings at the Ichmoul mine site. The authors also thank Dr Asma Boudria, for his help in improving the language of this manuscript. They also 
acknowledge Mr Ahmed Belhocine, director of SOMIBAR company (ENOF, Algeria), for facilitating access to the old mine Ichmoul maps.

\section{REFERENCES}

[1] F. Bell, T. Stacey, D. Genske, "Mining subsidence and its effect on the environment: some differing examples," Environ. Geol., vol. 40, pp. 135-152, Dec. 2000, 10.1007/s002540000140.

[2] F.G. Bell, S.E.T. Bullock, T.F.J. Halbich, P. Lindsay, "Environmental impacts associated with an abandoned mine in the Witbank Coalfield, South Africa," Inter. J. Coal Geol., vol. 45, no. 2-3, pp. 195-216, Jan. 2001, 10.1016/S0166-5162(00)00033-1.

[3] K.D. Kim, S. Lee, H.J. Oh, et al., "Assessment of ground subsidence hazard near an abandoned underground coal mine using GIS," Environ. Geol., vol. 50, pp. 1183-1191, 2006, 10.1007/s00254-006-0290-5.

[4] C. Loupasakis,V. Angelitsa, D. Rozos,N. Spanou, "Mining geohazards - land subsidence caused by the dewatering of opencast coal mines: The case study of the Amyntaio coal mine, Florina, Greece,". Nat. Hazards, vol.70, pp. 675-691, 2014, 10.1007/s11069-013-0837-1.

[5] K. Ma, Y, Zhang, M. Ruan, J. Guo and T. Chai, "Land Subsidence in a Coal Mining Area Reduced Soil Fertility and Led to Soil Degradation in Arid and Semi-Arid Regions," Int. J. Environ. Res. Public Health, vol. 16:3929, Oct. 2019, 10.3390/ijerph16203929.

[6] X. Wu, XW. Jiang, YF. Chen, et al.,"The influences of mining subsidence on the ecological environment and public infrastructure: a case study at the Haolaigou Iron Ore Mine in Baotou, China," Environ. Earth. Sci., vol. 59:803, Feb. 2009, 10.1007/s12665-009-0076-7.

[7] T. Waltham, H.D. Park, J. Suh, M.H. Yu, H.H. Kwon, K.M. Bang, "Collapses of old mines in Korea,"Eng. Geol., vol.118, no.1-2, pp. 29-36, Feb.2011, 10.1016/j.enggeo.2010.11.007.

[8] A. Akgun, C. Kincal, and B. Pradhan, "Application of remote sensing data and GIS for landslide risk assessment as an environmental threat to Izmir city (west Turkey)," Environ. Monit. Assess., vol. 184, pp. 54535470, Sep. 2012, 10.1007/s10661-011-2352-8.

[9] W., Chen, H.R. Pourghasemi, and S.A. Naghibi, "Prioritization of landslide conditioning factors and its spatial modeling in Shangnan County, China using GIS-based data mining algorithms" Bull. Eng. Geol. Environ., vol. 77, pp. 611-629, May 2018, 10.1007/s10064-0171004-9.

[10] R. Kumar, and R. Anbalagan, "Landslide susceptibility mapping of the Tehri reservoir rim area using the weights of evidence method," J. Earth Syst. Sci., vol. 128:153, Jun. 2019, 10.1007/s12040-019-1159-9.

[11] Q. Wang, Y. Guo, W. Li, J. He, Z. Wu () "Predictive modeling of landslide hazards in Wen County, northwestern China based on information value, weights-of-evidence, and certainty factor," Geomat. Hazards Risk, vol.10, no.1, pp. 820-835, Jan. 2019, 10.1080/19475705.2018.1549111.

[12] S.A. Mohamed, M.E. El-Raey, "Vulnerability assessment for flash floods using GIS spatial modeling and remotely sensed data in El-Arish City, North Sinai, Egypt,” Nat. Hazards, vol.102, pp. 707-728, Jan.2020. 10.1007/s11069-019-03571-x.

[13] X; Wang, H. A. Xie, "Review on Applications of Remote Sensing and Geographic Information Systems (GIS) in Water Resources and Flood Risk Management," Water, vol. 10:608, May 2018, 10.3390/w10050608.

[14] M. Mohammady, H.R. Pourghasemi, and M. Amiri, “Assessment of land subsidence susceptibility in Semnan plain (Iran): a comparison of support vector machine and weights of evidence data mining algorithms," Nat. Hazards, vol. 99, pp. 951-971, 2019, 10.1007/s11069019-03785-Z

[15] A. Neshat and B. Pradhan, "Evaluation of groundwater vulnerability to pollution using DRASTIC framework and GIS," Arab. J. Geosci., vol.10:501, Nov. 2017, 10.1007/s12517-017-3292-6.

[16] X. WU, B. LI, and C. MA, "Assessment of groundwater vulnerability by applying the modified DRASTIC model in Beihai City, China," Environ. Sci. Pollut. Res., vol. 25, pp. 12713-12727, May 2018, 10.1007/s11356-018-1449-9.

[17] L. Duarte, J. Espinha Marques, A. C. Teodoro, "An Open Source GIS Based Application for the Assessment of Groundwater Vulnerability to Pollution" Environments, vol. 6, no. 7: 86, Jul. 2019, 10.3390/environments6070086. 2019

[18] Singha, S.S., Pasupuleti, S., Singha, S. et al., "A GIS-based modified DRASTIC approach for geospatial modeling of groundwater vulnerability and pollution risk mapping in Korba district, Central India," Environ. Earth Sci., vol. 78:628, Oct. 2019, 10.1007/s12665-0198640-2.

[19] A., Arabameri, K., Rezaei, H.R. Pourghasemi, et al., " GIS-based gully erosion susceptibility mapping: a comparison among three data-driven models and AHP knowledge-based technique," Environ. Earth Sci., vol. 77:628, Sep. 2018, 10.1007/s12665-018-7808-5.

[20] S.S. Biswas, P. Pani, "Estimation of soil erosion using RUSLE and GIS techniques: a case study of Barakar River basin, Jharkhand, India," Model. Earth Syst. Environ., vol. 1:42, 2015, 10.1007/s40808-015-00403 .
[21] Y. Farhan, S. Nawaiseh, "Spatial assessment of soil erosion risk using RUSLE and GIS techniques," Environ. Earth Sci., vol. 74, pp. 46494669, Sep. 2015, 10.1007/s12665-015-4430-7.

[22] D. Hou, D. O'Connor, P.;Nathanail, L. Tian, Ma, Y. “Integrated GIS and multivariate statistical analysis for regional scale assessment of heavy metal soil contamination: A critical review," Environ. Pollut., vol. 231, no. 1, pp. 1188-1200, Dec. 2017, 10.1016/j.envpol.2017.07.021.

[23] W. Jia, G. Wang, "Multiple level prospectivity mapping based on 3D GIS and multiple geoscience dataset analysis: a case study in LuanchuanPb-Zn district, China," Arab. J. Geosci., vol. 12:332, 2019, 10.1007/s12517-019-4495-9.

[24] N. Li, X. Song, C. Li, et al., "3D Geological Modeling for Mineral System Approach to GIS-Based Prospectivity Analysis: Case Study of an MVT Pb-Zn Deposit," Nat. Resour. Res., vol. 28, pp. 995-1019, Jul. 2019, 10.1007/s11053-018-9429-9.

[25] L., Liu, J., Lu, C. Tao, et al., "GIS-based Mineral Prospectivity Mapping of Seafloor Massive Sulfide on Ultraslow-spreading Ridges: A Case Study of Southwest Indian Ridge $48.7^{\circ}-50.5^{\circ}$ E, " Nat. Resour. Res., Jan. 2021, 10.1007/s11053-020-09797-y.

[26] X. Mao, W. Zhang, Z. Liu, J. Ren, R.C. Bayless, H. Deng, “ 3D Mineral Prospectivity Modeling for the Low-Sulfidation Epithermal Gold Deposit: A Case Study of the Axi Gold Deposit, Western Tianshan, NW China,". Minerals, vol.10, no.3:233, Mar.2020, 10.3390/min1003023.

[27] Y. Choi, J. Baek, S. Park, "Review of GIS-Based Applications for Mining: Planning, Operation, and Environmental Management," Appl. Sci., Apr.2020, vol.10, no. 7:2266, 10.3390/app10072266.

[28] K.D. Kim, S., Lee, H.J. Oh, et al., "Assessment of ground subsidence hazard near an abandoned underground coal mine using GIS," Environ. Geol., vol. 50, pp. 1183-1191, may. 2006, 10.1007/s00254-006-0290-5.

[29] J. Blachowski, "Application of GIS spatial regression methods in assessment of land subsidence in complicated mining conditions: case study of the Walbrzych coal mine (SW Poland)," Nat. Hazards, vol. 84, pp. 997-1014, Jul.2016, 10.1007/s11069-016-2470-2.

[30] H. Oh, S. Ahn, J. Choi, et al., "Sensitivity analysis for the GIS-based mapping of the ground subsidence hazard near abandoned underground coal mines," Environ. Earth. Sci., vol. 64, pp. 347-358, Sep. 2011. 10.1007/s12665-010-0855-1

[31] S. Lee, I. Park, J.K. Choi,"Spatial Prediction of Ground Subsidence Susceptibility Using an Artificial Neural Network" Environ. Manag., vol. 49, pp. 347-358, Oct. 2012, 10.1007/s00267-011-9766-5.

[32] J.K. Choi, K.D. Kim, S. Lee, et al., "Application of a fuzzy operator to susceptibility estimations of coal mine subsidence in Taebaek City, Korea," Environ. Earth. Sci., vol. 59, pp. 1009-1022, Jan. 2010, 10.1007/s12665-009-0093-6.

[33] I. Park, et al., "Application of an adaptive neuro-fuzzy inference system to ground subsidence hazard mapping," Comput. Geosc., vol.48, pp. 228-238, Nov. 2012, 10.1016/j.cageo.2012.01.005.

[34] . J. Oh, S. Lee, " Integration of ground subsidence hazard maps of abandoned coal mines in Samcheok, Korea," Inter. J. Coal Geol., vol. 86, no.1, pp. 58-72, Apr. 2011, 10.1016/j.coal.2010.11.009.

[35] H. J. Oh, S. Lee, "Assessment of ground subsidence using GIS and the weights-of-evidence model,” Eng. Geol., vol. 115, pp. 36-48, Jul. 2010, 10.1016/j.enggeo.2010.06.015.

[36] N. Larachi, A. Bali, M. OuldHamou, S. Bensaadi, " Recovery of lead and barite from the abandoned Ichmoul mine wastes in Algeria," Environ. Earth Sci., vol.78:601, Oct. 2019, 10.1007/s12665-019-85935 .

[37] M. Daoud “ Mise en exploitation du gisement de djebel Ichmoul,”. Mémoire de fin d'études, ingéniorat, Dep. Metallurgie, ENP, ElHarrach, 1974

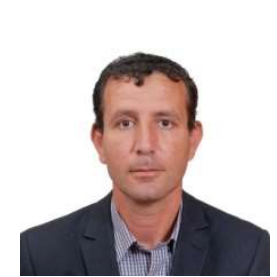

Nassim LARACHI received a Magister degree from the Ecole Nationale Polytechnique in Mining Engineering, in 2004. He is currently preparing a doctoral thesis on the wastes and the mining voids of mines sites abandoned. He works as an associate professor at Abderrahmane Mira university of Bejaia. His research interests are mining geology, mining exploitation, mine wastes and ores processing, mineinformatics and mining environment.

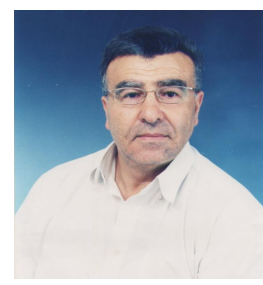

Abderrahim BALI is Professor and research director in Civil Engineering at Ecole Nationale Polytechnique Algiers, Algeria. He holds a PhD from Aston University in Birmingham (GB). He is involved in research activities and supervisions of Master and Doctorate's 
several national companies. He is a member of ACI (Algeria Chapter), and several technical committees for national and international research projects. His field of research and expertise includes microstructure, cementitious additions, recycling, local materials, fire resistance and durability of concrete.

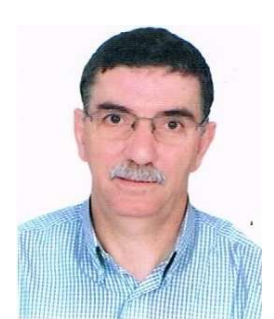

Abderrezak AIT YAHIATENE is born on 05/03/1957, in Tizi-Ouzou (Algeria), is a retired associate Professor from the Mining Engineering Department of Ecole Nationale Polytechnique, Algiers, Algeria. $\mathrm{He}$ received the Doctorate degree from AKADEMIA GORNICZO HUTNICZA (AGH) KRAKOW POLAND, in June 1987. He has successfully supervised many engineer, MSc and magister students at Ecole Nationale Polytechnique (ENP, Algiers). His research interests are in the areas of engineering mining, mining economy and mine-informatics.

Malek OULD HAMOU is a professor at Ecole Nationale Polytechnique Algiers, Algeria. He was the head of mining engineering department and the director of the mining engineering laboratory of the same establishment. His research interests are mineralurgy, bio-processing and mining environment. 